\title{
Determination of the Refractive Parameters in $\mathrm{Tl}_{3} \mathrm{TaS}_{4}$
}

\author{
O.V. Bokotey*, O.O. Bokotey, V.A. Slyvka, A.G. Slivka \\ Uzhhorod National University, 3, Narodna Sq., 88000 Uzhhorod, Ukraine
}

(Received 06 April 2020; revised manuscript received 15 December 2020; published online 25 December 2020)

\begin{abstract}
Theoretical calculations of the refractive index, optical dielectric constant and reflection coefficient for the $\mathrm{Tl}_{3} \mathrm{TaS}_{4}$ crystal within Harrison's bonding orbital model were carried out. The detailed analysis of our calculations has been done to present deeper understanding of this investigation. The calculations were performed for the spectral region far from the absorption edge, where the dispersion of the refractive index is absent. The refractive index was determined within the generalized single-oscillator model. This approach allows determining the energies of occupied electronic states using the Hartree-Fock values for the valence levels in solids. We have used the simplification by including only nearest-neighbor couplings (clusters) and using universal parameters, which allows direct prediction of crystal physical properties. This cluster approximation based on a special point is used for calculations of bond polarizabilities. The real part of the dielectric function is determined from the imaginary part by the Kramers-Kronig relationship. Finally, we have used the Moss, Ravindra, Herve and Vandamme models for comparing the value of the refractive index calculated according the Harrison's model. The satisfactory agreement of our theoretical calculations is obtained. It was shown that Harrison's model allows analyzing the optical parameters of $\mathrm{Tl}_{3} \mathrm{XY}_{4}$ type compounds. The refractive index evaluation is of considerable importance for applications in integrated optic devices, where refractive index of materials is the key parameter for device design. The theoretical technique developed in this paper could be used for the investigation of the optical properties of materials. It should be noted that the crystal under investigation is expected to contribute to the development of nanophysics and personalized medicine for health monitoring and prevention.
\end{abstract}

Keywords: Thallium tantalum sulfide, Nanophysics, Refractive index, Dispersion, Polarization.

DOI: 10.21272/jnep.12(6).06022

PACS numbers: 31.10. + z, 42.25.Ja, 42.65.An

\section{INTRODUCTION}

$\mathrm{Tl}_{3} \mathrm{TaS}_{4}$ crystal, one of the ternary thallium chalcogenide materials, belongs to the $\mathrm{Tl}_{3} \mathrm{XY}_{4}(\mathrm{X}=\mathrm{V}, \mathrm{Nb}$, Ta; $\mathrm{Y}=\mathrm{S}$, Se) family of compounds. They are isomorphic and crystallize in space group $\mathrm{T}_{\mathrm{d}}{ }^{3}-\mathrm{I} 43 \mathrm{~m}$. The crystal structure is characterized by isolated XY - tetrahedra in parallel orientation with $\mathrm{X}$ atoms forming a bodycentered cubic lattice, $\mathrm{Tl}$ occupies the middles of the edges and faces of the unit cell. The main feature of ternary thallium chalcogenides is the formation of numerous polymorphic modifications and existence of isomorphic substitutions in sublattices. Interest in them is caused by the ability to form continuous rows of solid solutions that allows to use them for different variations of physical and chemical properties. The specific feature of the mentioned structures is the presence of $\left[\mathrm{XY}_{4}\right]$ and $\left[\mathrm{TlY}_{8}\right]$ structural complexes.

Due to their unique physical and chemical properties, these crystals in the form of nanoparticles have a wide range of applications in nonlinear optics. Theoretical studies of refractive properties give the detailed information about properties of solids. Origin of the chemical bonding in crystals is very important for the definition of physical and chemical properties. The refractive index evaluation is of considerable importance for applications in integrated optic devices, where refractive index of materials is the key parameter for device design.

The main goal of this work is to establish refractive parameters of $\mathrm{Tl}_{3} \mathrm{TaS}_{4}$ crystal using the Harrison bonding orbital model. Obtained results are compared with calculation data of the well-known energy gap- refractive index relations. Such a study for $\mathrm{Tl}_{3} \mathrm{TaS}_{4}$ has not been carried out before. This investigation gives fundamental information, data and experiences for further studies.

\section{CRYSTAL STRUCTURE OF $\mathrm{Tl}_{3} \mathrm{TaS}_{4}$}

The structure of $\mathrm{Tl}_{3} \mathrm{TaS}_{4}$ is formed from endless chains along three coordinate directions, which consist of coordinated tetrahedrons of Ta atoms and octahedrons of $\mathrm{Tl}$ atoms. These octahedrons are tetragonal antiprisms with dihedral basis. Fig. 1 shows a general view of the $\mathrm{Tl}_{3} \mathrm{TaS}_{4}$ crystal structure.

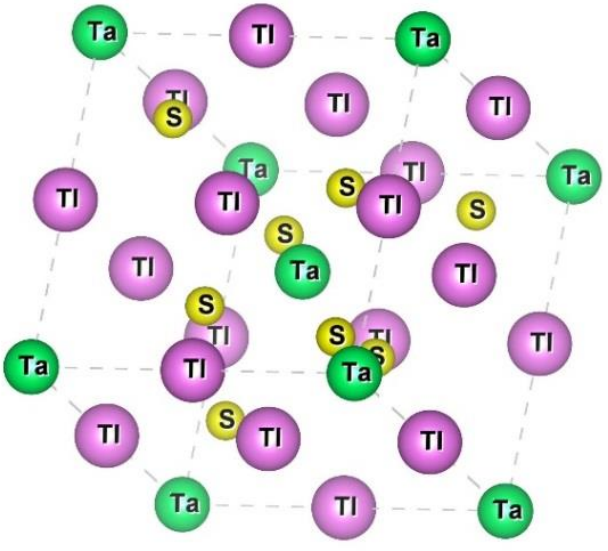

Fig. 1 - Crystal structure of $\mathrm{Tl}_{3} \mathrm{TaS}_{4}$

The Ta-S bond length is $2.39 \AA$, while the Tl-S bond length is $3.14 \AA$. These bonds form coordinated

\footnotetext{
*bokotey_ov@ukr.net
} 
tetrahedrons. The cubic lattice parameters are $a=7.67 \AA, \alpha=\beta=\gamma=90^{\circ}$. The crystal lattice is bodycentered. Atoms occupy the positions: $6 \mathrm{Tl}$ (b) [0 0.5 0.5], $2 \mathrm{Ta}$ (a) $\left[\begin{array}{lll}0 & 0 & 0\end{array}\right], 8 \mathrm{~S}$ (c) $\left[\begin{array}{llll}0.18 & 0.18 & 0.18\end{array}\right]$. The number of formula units in the unit cell is $Z=2$. The elementary cell contains sixteen atoms, including six Tl, two Ta, and eight $\mathrm{S}$. Ta atoms are tetrahedral surrounded by sulfide atoms and form molecular anions $\left[\mathrm{TaS}_{4}\right]^{3-}$ with $\mathrm{T}_{\mathrm{d}}$ symmetry, while $\mathrm{Tl}^{+}$cations occupy the positions with $\mathrm{D}_{2 \mathrm{~d}}$ symmetry.

\section{METHOD}

Optical properties for $\mathrm{Tl}_{3} \mathrm{TaS}_{4}$ were calculated according to the model proposed by Harrison [1-4]. The refractive index in the spectral region far from the absorption edge was determined within the generalized single-oscillator model. This approach allows determining the energies of occupied electronic states using the Hartree-Fock values for the valence levels in solids. One may start from the simplification by including only nearest-neighbor couplings and using universal parameters, which allows direct prediction of physical properties. All matrix elements between the bonding and anti-bonding states are neglected. For Harrison's model, this approach reduces a Hamiltonian matrix to two matrixes, one of which is constructed from the valence band states and another one - from the conduction band states. The use of Wannier functions provides zeroing of matrix elements between the bonding and anti-bonding states in the matrix. As a result, one can obtain the diagonal matrix elements, which correspond to Wannier energy levels, as well as matrix elements between the bonding states, responsible for splitting of these levels in bands. The Wannier's functions allow to accurately calculate the band structure. They are determined by the exact wave functions of the electronic states in the crystal. Finally, these theoretical calculations are compared with data obtained from empirical relations proposed by Moss, Ravindra, Herve, and Vandamme.

\section{RESULTS AND DISCUSSION}

Occupied energy levels with the largest energy define the properties of compounds. Valence electrons determine the optical properties of solids as the energy intervals of their excited electronic states are located in the optical range. The predicted optical parameters of $\mathrm{Tl}_{3} \mathrm{TaS}_{4}$ have been calculated from their molecular properties using the generalized single-oscillator model. In previous theoretical studies $[2,3]$ it was shown that Harrison's model allows calculating the refractive properties of solids. Moreover, it provides a new perspective on a macroscopic scale in materials for predicting the refractive index.

According to the special points method, an average of any property over the electronic energy band is replaced by the value at a single special wavenumber, the Baldereschi point $k$ [1-5]. This wavenumber is chosen in such a way that the first few sets of Fourier components of the band vanish, just as one would choose a point halfway to the Brillouin zone boundary in a onedimensional crystal. The character of the chemical bond depends on the total energy of the crystal and on the sum of energies of all occupied energy bands. As follows from the generalized single-oscillator theory, the interaction between orbitals of cation and anion is described by the energy:

$$
E_{k}=\frac{E_{s}+E_{p}}{2} \pm \sqrt{\left(\frac{E_{s}-E_{p}}{2}\right)^{2}+f(k)^{2} V_{s p \sigma}{ }^{2}},
$$

where $f(k)$ depends on the relative phase and orientation of neighboring orbitals. Of principal importance is the role of the chemical bonding type. The covalent bond arises due to the significant degree of the hybridization and electro-negativity differences between the atoms. Further improvement of these calculations requires optimization for different interaction cases:

$$
\begin{aligned}
& V_{s p \sigma}=1.42\left(\frac{h^{2}}{m d^{2}}\right), V_{p p \sigma}=2.22\left(\frac{h^{2}}{m d^{2}}\right), \\
& V_{p p \pi}=-0.63\left(\frac{h^{2}}{m d^{2}}\right)
\end{aligned}
$$

The contributions to the physical properties depend upon the coupling between neighboring orbitals and their energy difference $E_{s}-E_{p}$ taken from the HartreeFock term values. According to the generalized singleoscillator model, the ionic bond energy is equal to half the term-value difference:

$$
V_{3}=\frac{E_{s}-E_{p}}{2}
$$

From the aspects of fundamental solid-state physics refractive parameters are closely related to the electronic polarizability of ions and the local field inside the material. The cluster approximation based upon the special point is used for calculating bond polarizabilities. It is necessary to calculate the coupling of each occupied band state to every empty state, evaluate the change in charge on every atom, and the sum of contributions of the resulting perturbed electron density to obtain a dipole and the exact polarizability. The cluster consists of different states on each of the two neighbors. The bond polarizability is calculated as:

$$
\alpha=\gamma \frac{\left(1-\alpha_{p}\right) \alpha_{p} e^{2} d^{2}}{\left(1+\alpha_{p}\right) V_{3}}
$$

where $\alpha_{p}$ is the polarity defined as:

$$
\alpha_{p}=\frac{V_{3}}{\sqrt{V_{2}^{2}+V_{3}^{2}}} .
$$

The dielectric properties of the crystals are determined by the energy bands of the $p$-type, which become degenerate at the $\Gamma$ point. The dielectric susceptibility is the measure of the crystal response on the electromagnetic field. The optical dielectric susceptibility is calculated as the sum of polarizabilities of each bond type by their number per unit volume $[6,7]$. The refractive parameters are important in determining the elec- 
tric and optical properties of the materials. The imaginary part of the dielectric constant shows how a dielectric absorbs energy from an electric field caused by dipole motion. The magnitude of the imaginary part depends on the density of the occupied and unoccupied electron states and on the strength of the oscillator, which characterizes bonds of these states. The imaginary part of the dielectric susceptibility is responsible for absorption and associated with electron transitions between different states in the solids. It is one of the most direct methods for determining the structure of energy bands.

The real part of the dielectric function can be derived from the imaginary part by the Kramers-Kronig relationship. The refractive index is estimated with the following relation:

$$
n(\omega)=\left[\frac{\varepsilon_{1}(\omega)}{2}+\frac{\sqrt{\varepsilon_{1}^{2}(\omega)+\varepsilon_{2}^{2}(\omega)}}{2}\right]^{\frac{1}{2}},
$$

where $\varepsilon_{1}$ and $\varepsilon_{2}$ are the real and imaginary components of the dielectric function, respectively. The refractive index in the case of low magnetic permeability values equals:

$$
n=\sqrt{\varepsilon} .
$$

According to the Moss model [8], the refractive index is calculated from the relation:

$$
n^{4} \times E_{g}=K \text { with } K=95 \mathrm{eV} .
$$

Following the Ravindra model [8], the refractive index is given by:

$$
n=4.084-0.62 \times E_{g} .
$$

Herve and Vandamme [9] have proposed the relationship for the refractive index based on the oscillatory theory:

$$
n^{2}=1+\left[\frac{A}{E_{g}+B}\right]^{2} \text {. }
$$

\section{REFERENCES}

1. W. Harrison, Phys. Rev. B 74, 20, 205101 (2006).

2. O.V. Bokotey, Nanoscale Res. Lett. 11, 251 (2016).

3. O.V. Bokotey, I.P. Studenyak, I.I. Nebola, Yu.V. Minets, J. Alloy. Compd. 660, 193 (2016).

4. W.A. Harrison, World Scientific, Singapore (2004).

5. O.V. Bokotey, IEEE International Young Scientists Forum on Applied Physics and Engineering, 122 (Lviv: Ukraine, LNU: 2017).
From the experimental studies of absorption edge for $\mathrm{Tl}_{3} \mathrm{TaS}_{4}$, the optical band gap is estimated to be about $2.7 \mathrm{eV}$.

Table 1 and Table 2 show the macroscopic physical parameters used in the calculations and sum up the calculation results.

Table 1 - Physical parameters of $\mathrm{Tl}_{3} \mathrm{TaS}_{4}$

\begin{tabular}{|c|c|c|c|c|c|c|}
\hline $\begin{array}{c}\text { Bond } \\
\text { type }\end{array}$ & $d, \AA$ & $N_{c}$ & $\begin{array}{c}V_{2}, \\
\mathrm{eV}\end{array}$ & $\begin{array}{c}V_{3}, \\
\mathrm{eV}\end{array}$ & $\gamma$ & $a, \AA^{3}$ \\
\hline Ta-S & 2.39 & 2 & 2.65 & 1.02 & 0.33 & 44.92 \\
\hline Tl-S & 3.14 & 2 & 1.54 & 3.18 & 0.33 & 0.86 \\
\hline
\end{tabular}

Table 2 - Refractive parameters of $\mathrm{Tl}_{3} \mathrm{TaS}_{4}$

\begin{tabular}{|c|c|c|c|c|}
\hline$n$, Harris. & $R$ & $n$, Moss & $n$, Rav. & $n$, Herv. \\
\hline 2.698 & 0.21 & 2.44 & 2.41 & 2.44 \\
\hline
\end{tabular}

$N_{c}$ is the coordination number, $d$ is the bond length, $V_{2}$ is the energy of the covalent bond, $V_{3}$ is the energy of the ionic bond, $\gamma$ is the coefficient, $\alpha$ is the polarizability, $\chi$ is the susceptibility, $n$ is the refractive index, $R$ is the reflection coefficient.

The magnitudes of the refractive index obtained from equations (8)-(10) are 2.44, 2.41 and 2.44. It is in good agreement with the value calculated according to the Harrison's model $(n=2.698)$. However, some deviations may be explained by the existence of defects of the crystal structure.

\section{CONCLUSIONS}

In the present paper, the Harrison's bonding orbital method for calculation of the refractive index, optical dielectric constant and reflection coefficient of the $\mathrm{Tl}_{3} \mathrm{TaS}_{4}$ crystal is considered. The idea of the proposed method consists in using the generalized singleelectron model in the spectral region far from the absorption edge. It was established that the refractive index is equal to 2.7 for $\mathrm{Tl}_{3} \mathrm{TaS}_{4}$. A satisfactory correlation between the experimental data and the results of our theoretical calculations is obtained. It follows from the theoretical considerations that Harrison's approach is a convenient and flexible method for the study of optical properties of the $\mathrm{Tl}_{3} \mathrm{XY}_{4}$ compounds.

6. O.V. Bokotey, M.I. Chavarha, O.O. Bokotey, VI International Conference: Medical physics - the current status, problems, the way of development. Innovation technologies, 116 (Kyiv, Ukraine, KNU: 2017).

7. O.V. Bokotey, 4th International Conference "Nanotechnologies" (Nano-2016), 33 (Tbilisi, Georgia, TNU: 2016).

8. R.R. Reddy, K.R. Gopal, K. Narasimhulu, L.S.S. Reddy, K.R. Kumara, C.V.K. Reddy, S.N. Ahmed, Opt. Mater. 31, 209 (2008).

9. P.J.L. Herve, L.K.J. Vandamme, Infrared Phys. 35, 609 (1994). 


\title{
Визначення рефрактивних параметрів в кристалі $\mathrm{Tl}_{3} \mathrm{TaS}_{4}$
}

\author{
О.В. Бокотей, О.О. Бокотей, В.О. Сливка, О.Г. Сливка
}

Ужгородський національний університет, пл. Народна, 3, 88000 Ужгород, Украйна

Проведено теоретичні розрахунки показника заломлення, оптичної діелектричної проникності та коефіціента відбивання для кристала $\mathrm{Tl}_{3} \mathrm{TaS}_{4}$ в рамках моделі зв'язуючих орбіталей Харрісона. Для глибшого розуміння цього дослідження представлено детальний аналіз наших розрахунків. Розрахунки проводились для спектральної області, далекої від краю поглинання, де дисперсія показника заломлення відсутня. Показник заломлення визначений в рамках узагальненої одноелектронної моделі. Цей підхід дозволяе визначати енергії заповнених електронних станів за допомогою значень термів Хартрі-Фока для валентних рівнів в твердих тілах. Ми використали спрощення, включивши лише найближчі зв'язки (кластери) та використовуючи універсальні параметри, що дозволяе безпосередньо прогнозувати фізичні властивості кристалів. Це кластерне наближення, яке базуеться на спеціальній точці, використовуеться для розрахунків поляризованості зв'язку. Дійсну частину діелектричної функції визначено з уявної частини співвідношенням Крамерса-Кроніга. 3 рештою, ми використали моделі Мосса, Равіндри, Ерва та Вендама для порівняння із значенням показника заломлення, розрахованого в рамках моделі Харрісона. Отримано задовільне узгодження наших теоретичних розрахунків. Показано, що модель Харрісона дозволяе аналізувати оптичні параметри сполук типу $\mathrm{Tl}_{3} \mathrm{XY} 4$. Оцінка показника заломлення мае важливе значення для застосування в інтегрованих оптичних пристроях, де показник заломлення матеріалів е ключовим параметром для проектування пристроїв. Теоретична методика, розроблена в цій статті, може бути використана для дослідження оптичних властивостей матеріалів. Слід зазначити, що досліджуваний кристал, як очікуеться, сприятиме розвитку нанофізики та персоналізованої медицини для моніторингу та профілактики здоров'я.

Ключові слова: Сульрід танталату талію, Нанофізика, Показник заломлення, Дисперсія, Поляризація. 